\title{
Identification of lipase producing bacteria from palm oil sewage sludge processing plant at Malimping, Banten, Indonesia
}

\author{
IKA RAHMATUL LAYLY ${ }^{1, \bullet}$, ANJA MERYANDINI ${ }^{1}$, IS HELIANTI $^{2}$, RIKA INDRI ASTUTI ${ }^{1}$ \\ ${ }^{1}$ Department of Biology, Faculty of Mathematics and Natural Sciences, Institut Pertanian Bogor. Jl. Agatis, IPB Dramaga Campus, Bogor 16680, West \\ Java, Indonesia. Tel./fax.: +62-251-8622833, ‘email: Ika.layly@gmail.com \\ ${ }^{2}$ Agency for the Assessment and Application of Technology. Building 610, Laptiab, Puspiptek, Serpong, South Tangerang 15310, Banten, Indonesia
}

Manuscript received: 27 May 2021. Revision accepted: 27 September 2021.

\begin{abstract}
Layli IR, Meryandini A, Helianti I, Astuti RI. 2021. Identification of lipase-producing bacteria from palm oil sewage sludge processing plant at Malimping, Banten, Indonesia. Biodiversitas 22: 4512-4524. Lipase (triacylglycerol hydrolase E.C.3.1.1.3) is an enzyme that catalyzes the hydrolysis reaction of triacylglycerol into free fatty acids and glycerols. Lipase has broad application spectrum and unique catalytic mechanism, as one of important enzymes for industries, and almost all enzymes used for industries are originated from microbes. Identification of lipase-producing bacteria from palm oil processing sewage sludge was carried out to determine the potential of isolates and the application of lipase enzymes for industry. This study identified lipase-producing bacteria from the screening and isolation results from palm oil sewage sludge in Malimping-Banten. Two isolates were obtained from screening and isolation results. The morphological and observation and Gram staining method resulted in mlp-1 colony isolate was Gram-negative with basil cell shape, while mlp-2 colony isolate was Gram-positive with basil cell shape. Qualitative test on two isolates in tributyrin agar showed that two isolates produced clear zone or lipase enzyme. Molecular identification using 16SrRNA sequence showed that mlp-1 colony isolate was Chryseobacterium gleum, while mlp-2 colony was Bacillus velezensis. Literature study stated that Chryseobacterium gleum are pathogenic bacteria, resulting in uncontinued identification process, while Bacillus velezensis are nonpathogenic bacteria that have potential for industrial application. Identification of Bacillus velezensis was continued by performing biochemical test and inhibitory test. The continued identification results supported the molecular identification of lipase-producing enzyme for Bacillus velezensis.
\end{abstract}

Keywords: 16SrRNA molecular identification, Bacillus velezensis, biochemical test, inhibitory test, lipase enzyme

\section{INTRODUCTION}

The biotechnology industry, also known as green technology is a modern biotechnological application for sustainable production of chemicals, materials, and fuels from renewable resources using living cells or their enzyme products. Industrial biotechnology becomes very attractive as its application can save energy, reduce gas emissions, and be environmentally friendly. Biotechnological development has been very fast after involving enzymes and microbes (Gurung et al. 2013).

Enzyme is biocatalysator that plays important role in biological processes and becomes one of main components in various application processes in the industry. Environmental pollution and strict governmental regulation to apply green technology in each industry cause high enzyme production demand. Hydrolase enzyme is an enzyme that takes over $70 \%$ of demands in industrial share. Lipase as part of hydrolase group remains in third place after protease and carbohydrase (Li et al. 2012). Widely substrate usage and catalyzed reaction assisted, compared to other enzymes, causes lipase as important enzyme in industries with many applications among food, non-food, and health industries (Verma et al. 2012).

Lipase (triacyl glycerol hydrolase E.C.3.1.1.3) is an enzyme that catalyzes hydrolysis reaction of triacylglycerols into free fatty acids and glycerols. Lipase is found in nature and produced by plants, animals, and microorganisms (Hasan et al. 2006). However, enzymes from bacteria are more preferable to enzymes from fungi or molds. This condition is because bacteria have shorter generation period, simpler nutrient requirements, and easier screening procedures (Jaeger and Eggert 2002). Several genera for lipase-producing bacteria are Bacillus, Pseudomonas, and Burkholderia (Verma et al. 2012).

From 1980 until today, lipase requirement for industries grows fast, due to various benefits, such as catalytic efficiency and high specificity, which causes higher lipase demand (Hasan et al. 2006). Massive demand for lipase for industrial application encourages further study about wider exploration and identification for lipase-producing microorganisms, which can obtain excellent isolates to support commercial enzyme production. Lipase-producing microorganisms such as yeast, molds, bacteria, and some protozoa are commonly found in soil habitats, especially in soils and areas containing high organic matter, fats, and oils. Microbes inhabiting soil habitats rich in oil or fat produce extracellular hydrolase enzymes for the substrate as a source of nutrients, and most of the hydrolase enzymes produced are lipase enzymes (Lee et al. 2015). According to Derawi et al. (2014), solid waste such as sludge from oil palm processing contains $75 \%$ water, $11.4 \%$ crude protein, and $10.14 \%$ crude fat. Palm oil processing waste in Malimping-Banten is estimated to be inhabited by 
microbes that produce lipase enzymes. Patel et al. (2016) succeeded in obtaining 2 isolates of lipase-producing bacteria of the genus Bacillus, isolated from palm oil waste in Bardoli-India. This study isolated and identified the lipase-producing bacteria from oil palm processing sewage sludge in Malimping-Banten.

\section{MATERIALS AND METHODS}

\section{Sampling location}

Samples were obtained from palm oil processing sewage sludge in Malimping Sub-district, Lebak District, Banten Province, Indonesia, at $105^{\circ} 11^{\prime} 11^{\prime \prime}-106^{\circ} 7^{\prime} 12 " \mathrm{E}$ and 57'50"'-7¹'1' S. (Figure 1).

Sampling lipase producing bacteria from sewage sludge

Sampling was performed on sewage sludge surface as the outlet stream from palm oil processing waste. Sampling was carried out on 2 spots. The first was performed on the sewage sludge surface, and the second was at a depth of 20 $\mathrm{cm}$ from the surface. Using water dipper, every $50 \mathrm{~mL}$ of sample from sewage sludge surface and sample from at a dept of $20 \mathrm{~cm}$ collected into sterile falcon.

\section{Isolation bacteria from palm oil sewage sludge samples in Malimping Sub-district}

Isolation was performed by diluting the samples obtained. Using Patel et al. (2016) methods. Dilution used sterile aquadest with serial dilution starting from $10^{-1}$ to $10^{-}$ 5 . From each serial dilution was taken $50 \mu \mathrm{L}$ triplicate and poured on Luria Bertani (LB) agar plates with pour-plate method. These plates were then incubated at $37^{\circ} \mathrm{C}$.

\section{Isolate purification from the isolation results}

Purification of isolates from the isolation results using Patel et al. (2016) method. Isolates from the isolation results grown in LB agar media were purified by taking different colonies and moving these colonies to LB media with quadrant streaking method and the media were incubated at $37^{\circ} \mathrm{C}$. From 15 plates 2 different purified colonies were obtained.

\section{Qualitative test for purified isolates in Tributyrin (TBA) agar media}

TBA agar media used for qualitative test and screening potential lipase isolate based on Glogauer et al. (2011). TBA agar media consist of Peptone $0.5 \%$, Beef extract $0.3 \%$, Tributyrin $1 \%$ and agar $1 \%$. Isolates from the purification results were taken from its single colony and grown on Tributyrin agar media, then incubated at $37^{\circ} \mathrm{C}$, and the clear zone formed was observed around the grown colony. The clear zone formed showed that the isolates from the isolation results produced lipase enzyme.

\section{Gram staining}

Gram staining was performed by preparing smearing sample on the object-glass. This method is based on $\mathrm{Li}$ et al. (2020). The liquid culture isolates on less than 24 hour period were used, using 14 hours liquid culture isolate. Object glass was then fixated above Bunsen until dry. Crystal violet solution was dropped on the object-glass and the object-glass was stood for 2 minutes, then rinsed with aquadest, alcohol $95 \%$ for 30 seconds, aquadest again. For the last step, Safranin staining was dropped on the objectglass for 30 seconds and rinsed back with aquadest. Sample was dried and observed under the microscope.
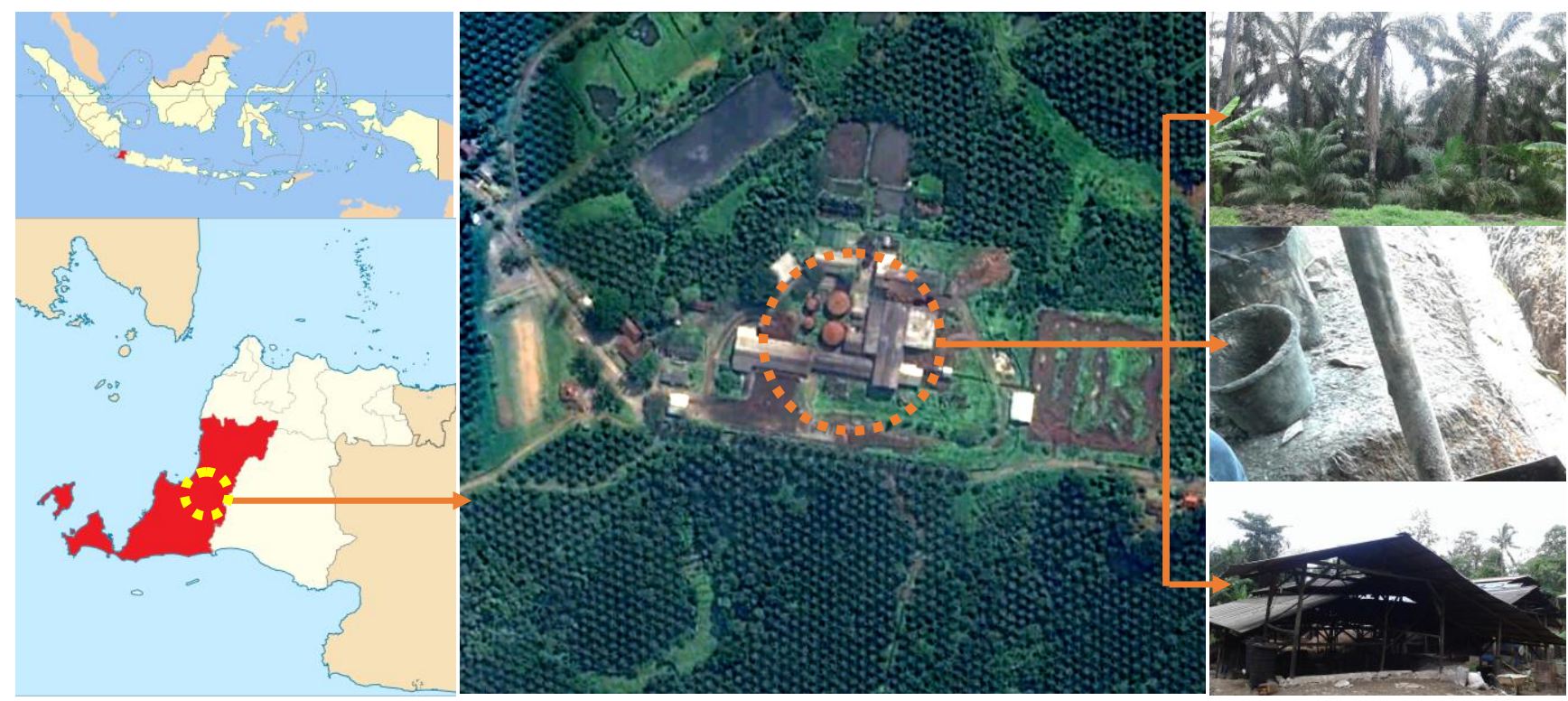

Figure 1. Sampling location in Malimping Sub-district, Lebak District, Banten Province, Indonesia 


\section{Morphological observation}

Bacterial identification using morphological observation by Li et al. (2020) methods. Morphological observation was performed by dropping $10 \mu \mathrm{L}$ of liquid culture isolate on 14 hour period on the object-glass and observing its morphology and motility under the light microscope. Using 100, 400 and 1000 magnification.

\section{Genome isolation from bacterial isolates after isolation}

Bacterial genome isolation was performed by using Presto ${ }^{T M}$ mini DNA Bacteria Kit Protocol Genaid kit. The method was based on Geneaid Instruction Manual (2017). There were five steps prepared for DNA isolation with kit. First step was bacterial culture preparation. Bacterial cells were grown on LB media and incubated for 18 hours at $37^{\circ} \mathrm{C}$. The culture was checked its optical density (OD) every 2 hours and harvested when the OD value reached 0.4-0.6 or until the cell reached approximately $1 \times 10^{9}$ cells $/ \mathrm{ml}$. Culture was taken at $1 \mathrm{~mL}$, moved to $1.5 \mathrm{ml}$ microtube, and centrifuged for 1 minute at 14,000 rpm, and the supernatant was removed. GT buffer was added in the sample following lysozyme $(0.8 \mathrm{mg} / 200 \mu \mathrm{L}$ concentration) addition. The sample was vortexed until the mixture was mixed evenly. The sample was incubated for 30 minutes at $37^{\circ} \mathrm{C}$, added by proteinase $\mathrm{K}$ at $20 \mu \mathrm{L}$ and incubated for 10 minutes at $60^{\circ} \mathrm{C}$, as the mixture was shaken every 3 minutes. The second step was cell lysis. Sample was added with $200 \mu \mathrm{L}$ buffer GB, resuspended, vortexed for 10 seconds, and incubated for 10 minutes at $70^{\circ} \mathrm{C}$, and the mixture was shaken every 3 minutes. The third step was DNA binding.

Sample was added with $200 \mu \mathrm{L}$ of absolute ethanol, resuspended until soluble without threads, and centrifuged at $4^{\circ} \mathrm{C}$ at $14,000 \mathrm{rpm}$ for 2 minutes. The fourth step was washing. Sample was added with $400 \mu \mathrm{L}$ Buffer WI in the GD column, centrifuged for 30 seconds at $14,000 \mathrm{rpm}$ in $4^{\circ} \mathrm{C}$, as the liquid part below the column was removed, followed by adding $600 \mu \mathrm{L}$ Wash buffer and centrifuging at $14,000 \mathrm{rpm}$ for 30 seconds, and recentrifuged for 3 minutes with the same temperature and speed. The fifth step or the last step was elution. New microtube was prepared and the GD column from the third step was moved to the microtube. The $50 \mu \mathrm{L}$ warm elution buffer was added to the GD column and stood for 5 minutes at room temperature, centrifuged at $14,000 \mathrm{rpm}$ for 30 seconds, and the eluted part (down from the GD column) was preserved at $-20^{\circ} \mathrm{C}$.

\section{S rRNA encoding gene region amplification from bacterial isolate}

The 16S rRNA region from the isolate was amplified using the PCR technique (Lane et al. 1985) based on the primers of 27F (5'-AGAGTTGATCCTGGCTCAG-3'), 1492R (5'-TACCTTGTTACGATT-3'). The PCR reacting composition contained $1 \mu \mathrm{L}$ 10x PCR buffer, $1 \mu \mathrm{L}$ dNTPs $(2 \mathrm{mM}), 1 \mu \mathrm{L}$ primer $27 \mathrm{f}(10 \mathrm{mM}), 1 \mu \mathrm{L}$ primer $1492 \mathrm{R}(10$ $\mathrm{mM}), 2 \mu \mathrm{L}$ DNA genome (100-200 ng), $1 \mu \mathrm{L}$ Taq

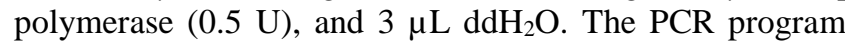
for this reaction was denaturation at $94^{\circ} \mathrm{C}$ for 1 minute, annealing at $50^{\circ} \mathrm{C}$ for 35 seconds, and extension at $72^{\circ} \mathrm{C}$ for 2 minutes. Total cycle performed was 30 cycles. In the final cycle, final extension was performed for 10 minutes.

\section{PCR product purification}

The PCR purification product purification used the extraction kit (Geneaid Gel/PCR DNA Fragments Extraction Kit). The method base on Geneaid Instruction Manual (2017). After PCR, the PCR product was run using the agarose gel to obtain the DNA band at around $1500 \mathrm{bp}$. The $1500 \mathrm{bp}$ band on the agarose gel was cut and taken 300 mg gel weight. This process was performed by cutting the gel below the UV transilluminator. Gel was moved to the microtube, added $500 \mu \mathrm{L}$ buffer $\mathrm{DF}$, vortexed, and incubated for 15 minutes at $60^{\circ} \mathrm{C}$. Next step was centrifugation at $16,000 \mathrm{rpm}$ for 30 seconds. Supernatant was removed and pellet was added with $400 \mu \mathrm{L}$ WI buffer, centrifuged at 16,000 rpm for 30 seconds, supernatant was removed, added with $600 \mu \mathrm{L}$ wash buffer, centrifuged at $16,000 \mathrm{rpm}$ for 30 seconds, and the supernatant was removed. Pellet was eluted with $20 \mu \mathrm{L}$ elusion buffer, centrifuged at $16,000 \mathrm{rpm}$ for 2 minutes, and the pellet obtained was from the purified PCR product.

\section{S rRNA sequencing result analysis}

The purification result of PCR product was sent to Genetika Science vendor for 16S rRNA region sequencing. The sequencing result obtained was identified its sequence similarity based on the online available database on www.ncbi.nlm.nih.gov by using the Nucleotide Basic Local Alignment Search Tool (Nucleotide BLAST).

\section{Motility observation}

Motility observation test using Bailey et al. (1974) methods. Isolate culture was inoculated perpendicularly on the Tryptone Soya Agar (TSA), added with phenol red indicator, incubated for 24 to 48 hours at $35-37^{\circ} \mathrm{C}$, and observed the distribution or movement existence on the agar.

\section{Catalase test}

One ose of culture isolate was placed on the objectglass dropped with $3 \% \mathrm{H}_{2} \mathrm{O}_{2}$ and observed the $\mathrm{O}_{2}$ bubble existence on the culture isolate.

\section{Oxidase test}

Isolate was inoculated on Nutrient Broth (NB) media and incubated at $30^{\circ} \mathrm{C}$ for 24 hours. The $1 \%$ alpha-naphthol and $0.3 \mathrm{ml} \mathrm{p}$-aminodimethylaniline-oxalate were dropped on the culture isolate and stood for 5 minutes to observe the blue color formation existence.

\section{Indole production test}

One ose of isolate was inoculated on the Tryptone Broth liquid media and incubated at $35-37^{\circ} \mathrm{C}$ for 24 hours. The Kovacs reagent was then added at $0.2-0.3 \mathrm{ml}$. Ring formed on the media was observed whether in red or yellow color. 


\section{Carbohydrate fermentation (glucose, fructose, sucrose)}

The 45 g/L Phenol Red Glucose Broth (PGRB) added with glucose, fructose, and sucrose at $5 \mathrm{~g} / \mathrm{L}$ in $7.4 \mathrm{pH}$ was added in each tube filled with Durham tube. One ose of culture isolate was inoculated in each tube and incubated at $37^{\circ} \mathrm{C}$ for 48 hours. Reaction was observed based on the indicator color changing on the medium and gas formation.

\section{Oxidation-fermentation test}

The oxidative-fermentative media (Hugh and Leifson's medium) was used to inoculate the isolate. Tubes filled with the media and isolates were remained opened and closed with paraffin oil at $1 \mathrm{~cm}$ height, and the isolate was incubated for 7 days at $37^{\circ} \mathrm{C}$ and observed the media colorchanging occurred.

\section{Urease test}

Urease agar medium was used to testify the urease activity on bacteria. The $10 \mathrm{ml}$ Urea agar in reaction tube was added with $40 \%$ urea at $0.5 \mathrm{ml}$. Isolate was inoculated on urea slant agar and incubated at $37^{\circ} \mathrm{C}$ for 24 hours. Color formation was observed in the media.

\section{Citrate test}

Bacterial isolate was inoculated on Simon citrate agar media, which was incubated for 96 hours at $37^{\circ} \mathrm{C}$, and the color changing in the media was observed.

\section{Voges Proskauer test}

Isolate was inoculated on the Methyl Red Voges Proskauer (MR-VP) media and inoculated at $37^{\circ} \mathrm{C}$ for 48 hours. The $1 \mathrm{~mL}$ of inoculated MR-VP medium was moved to the sterile reaction tube, added with $0.6 \mathrm{ml}$ alpha naphthol solution and $0.2 \mathrm{ml} \mathrm{KOH} 40 \%$, then shaken, added with creatine crystal, reshaken and stood for 2 hours, which was observed the color formation when the positive reaction occurred.

\section{Methyl red test}

The inoculated MR-VP medium used for Voges Proskauer test was also used for the methyl red test by incubating the medium at $37^{\circ} \mathrm{C}$ for 48 hours added with five drops of methyl red indicator. Red color formation was observed whether the positive reaction occurred.

\section{$\mathrm{H}_{2} \mathrm{~S}$ production}

To testify whether the bacteria could produce $\mathrm{H}_{2} \mathrm{~S}$, a test was performed by using the Triple Sugar Iron Agar (TSIA) medium was used. Isolate was inoculated on the TSIA slant agar and incubated at $37^{\circ} \mathrm{C}$ for 24 hours, and the change was observed on stand and slant position.

\section{Starch hydrolysis}

Isolate was inoculated on starch medium and incubated at $37^{\circ} \mathrm{C}$ for $48-72$ hours. The bacterial culture grown was dropped iodine solution. Color changing was observed around the culture, whether showing clear formation or not.

\section{Nitrate reduction}

By using the Nitrate broth and reagents to testify the nitrate-reducing bacteria. Isolate was inoculated on the Nitrate medium and incubated at $37^{\circ} \mathrm{C}$ for 24 hours, dropped with 3-4 drops of alpha-naphthylamine and sulfanilic acid. The color formation was observed after dropping the reagents.

\section{Isolate rejuvenation for antagonistic test}

The isolate tested its antagonistic activity against the isolated isolate sample was rejuvenated from the glycerol stock and grown on the LB medium. The isolate was incubated at $37^{\circ} \mathrm{C}$ for 24 hours. Eight isolates were used for antagonistic test, namely, Chryseobacterium gleum, Bacillus halodurans CM1, Bacillus megaterium, Bacillus stearothermophilus, Bacillus subtilis DB104, Bacillus lichenifromis F11.3, Lactobacillus lactis, and E. coli DH5 $\alpha$.

\section{Inhibitory test on the isolated isolates}

The isolated isolates and isolates used to testify the antagonistic level were inoculated on liquid LB media and incubated at $37^{\circ} \mathrm{C}$ for one night with $150 \mathrm{rpm}$ agitation. The liquid culture isolates for antagonistic test was taken $100 \mu \mathrm{L}$ and grown on LB agar medium using the pour plate method. Similar agar plate inoculated with liquid culture isolate for antagonistic test was dropped the liquid culture isolate from the isolation result in four-quadrant parts and incubated for 24-48 hours to observe its antagonistic effect.

\section{RESULTS AND DISCUSSIONS}

\section{Sampling and isolation of lipase enzyme-producing bacteria from palm oil processing sewage sludge}

Sampling was performed on sewage sludge surface as the outlet stream from palm oil processing waste. Sampling was carried out on the surface of the sewage sludge, and at a depth of $20 \mathrm{~cm}$ from the surface. Sampling with this method was to obtain aerobic microbes, because it is carried out at a point where there is still available free oxygen. Oil waste was abundant in the sewage as solid or liquid waste on the surface, which may possibly contain abundant microorganisms, including bacteria (Figure 2).

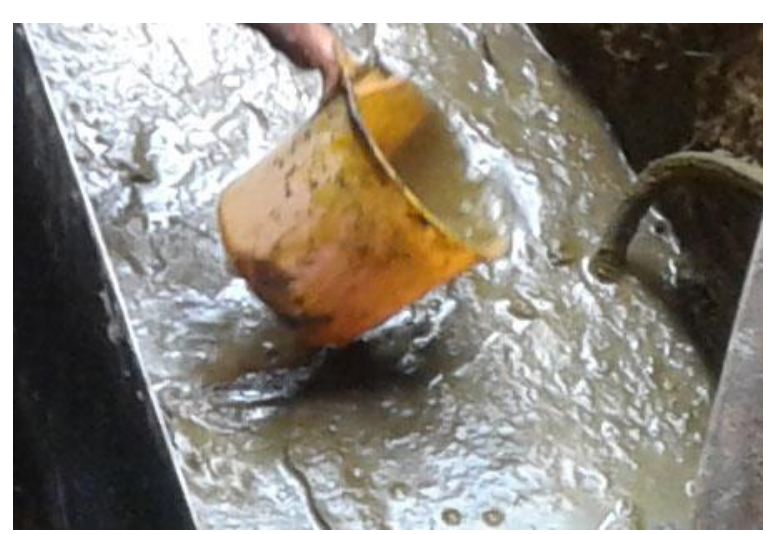

Figure 2. Sewage sludge 

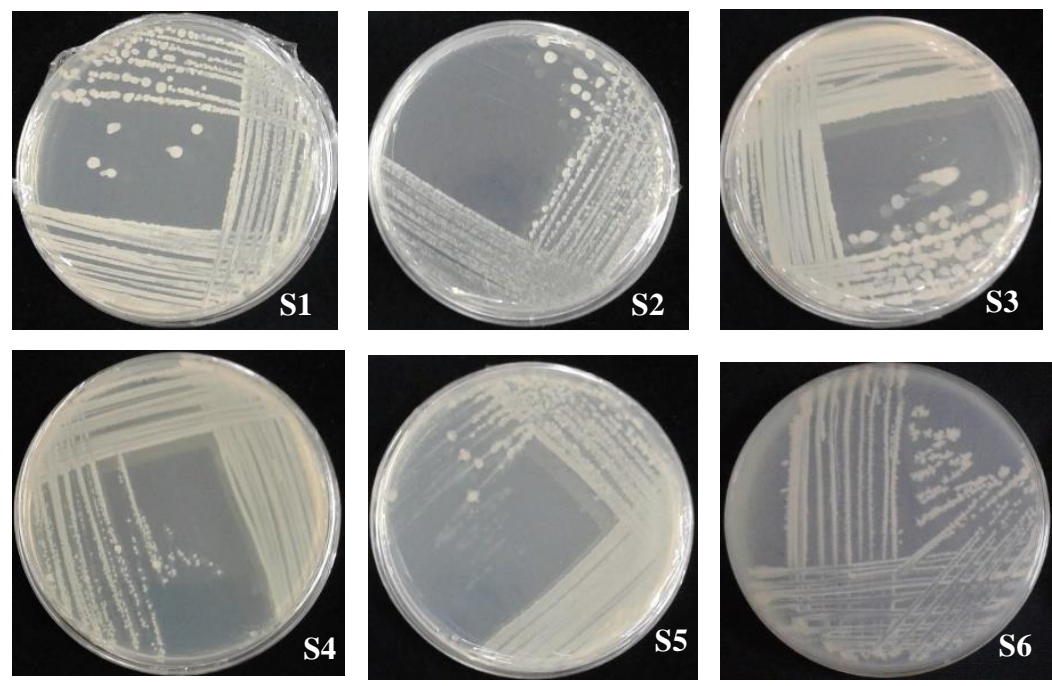

Figure 3. Screening and isolation of isolates. S1, S2, S3: The isolate obtained from sample purification at the point of the sewage sludge surface. S4, S5, S6: The isolate obtained from sample purification at a point at a depth of $10 \mathrm{~cm}$ from the surface of sewage sludge

Popoola and Onilude (2017) stated that lipaseproducing microbes mostly inhabit processing waste or contaminants from plant-based oil. Lee et al. (2015) supported this result, who successfully isolated lipolytic bacteria from industrial garbage, plant oil processing company, milk product and their derivatives, and oilcontaminated soil. These habitats were rich in oil and lipids as good environmental conditions for lipolytic bacteria to proliferate.

The screening and isolation results obtained six agar plates from six single bacterial colonies (Figure 3). The isolates were obtained grown on LB media. The LB media are nutrient-rich media used for bacterial proliferation. The LB media were created by Giuseppe Bertani in 1952 and used as Shigella proliferating media observed from the plaque formation (MacWilliam and Min 2006). The results of the screening obtained 6 isolates, 3 isolates obtained from the results of sampling on the surface of the sewer mud (S1-S3) and 3 other isolates obtained from the results of sampling at a point at a depth of $20 \mathrm{~cm}$ from the surface of the sewer mud (S4-S6). The six isolates obtained showed differences in the shape and color of the colonies. There were 2 isolates whose colonies were white and 4 isolates whose colonies were yellow. The white colonies have an irregular shape, while the yellow colonies are round. According to Madigan et al. (2009), several forms of bacterial colonies are punctiform, rhizoid, filamentous, irregular, spindle. While the colony colors include orange, black, brown, opaque or white and milky.

Six bacterial isolates were purified and observed based on the similarity of colony shape and color. 2 bacterial isolates with irregular colony shape and white color are the same isolates referred to as mlp-2 isolates. Meanwhile, 4 bacterial isolates with irregular colony shape and yellow color were also the same isolates, referred to as mlp-1 isolates (Figure 4). Six bacterial isolates in six agar plates were re-purified by inoculating them on the LB media. The purification results obtained 2 isolates with mlp- 1 colony and mlp-2 colony (Figure 4).

Purification of isolated bacteria obtained 2 single colonies with different morphology due to separation from other colonies or contaminants. The yellow colonies are called mlp-1 isolates and the white colonies are called mlp2 isolates. Purification aimed to obtain pure isolate, single colony without any microbial contaminants. The purified microbial colonies were selected based on morphological differences, such as color, surface texture, elevation, radial line, concentrical circle (Ed-Har et al. 2017). Purified isolate mlp-1 and mlp-2 were regrown and refresh on LB media, for further testing.

\section{Isolate potential test for lipase enzyme production on TBA media}

The mlp-1 and mlp-2 bacterial isolates were tested for their potential as lipolytic bacteria that produced lipase enzymes by growing them on Tributyrine Agar (TBA) media. The qualitative results of mlp-1 and mlp-2 bacterial isolates showed that both isolates could form clear zone around the colony (Figure 5).
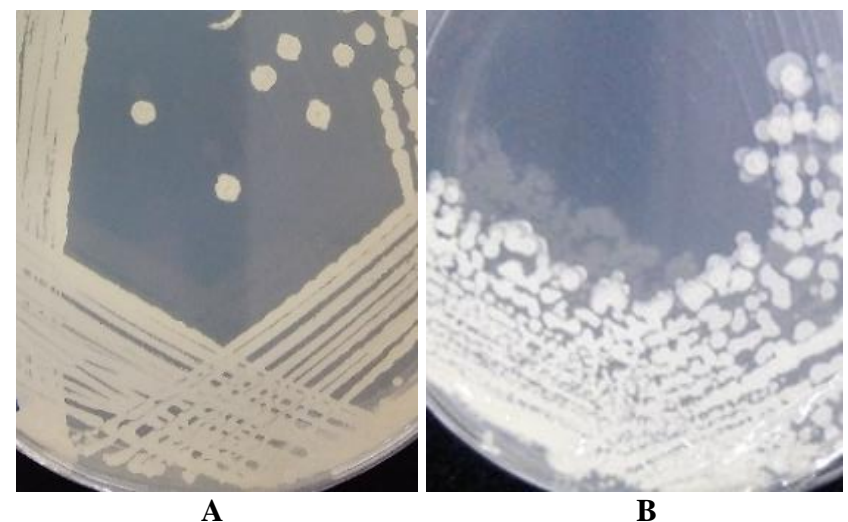

Figure 4. Purified isolate A. mlp-1 isolate, B. mlp-2 isolate 


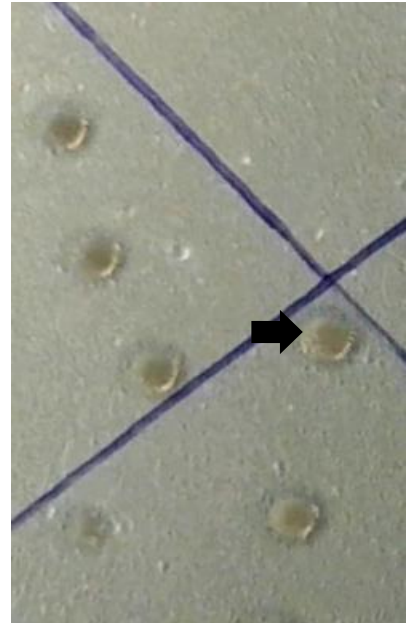

A

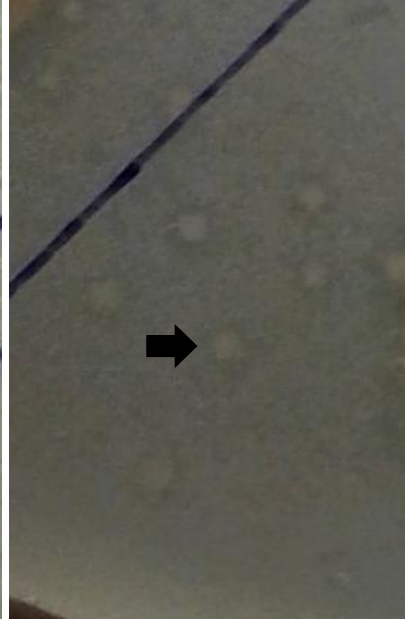

B
Figure 5. Clear zone on Tributyrin media, A. mlp-1 isolate, B. mlp-2 isolate

The clear zone formed around the A and B bacterial colony isolates on Tributyrin media after incubating for 24 hours indicates that both isolates have potential as lipaseproducing enzyme bacteria that can hydrolyze lipid in Tributyrin media. Palafox et al. (2018) stated that tributyrin agar (TBA) or blue spirit agar was used to determine the lipolytic bacteria. TBA media are commonly used for lipolytic bacterial screening by observing the existence of clear zone around the colony. The clear zone formed showed lipase or esterase activities. Haba et al. (2000) stated that TBA media were also used for strain selection after 72-hour to 7-day incubations besides identifying the lipolytic activity. In line with Ma et al. (2010), TBA is the most commonly used media for screening lipolytic strains by developing a clear zone around the colony, as indicative of lipase or esterase activity.

\section{Isolate Gram staining and morphological observation}

Gram staining was performed to identify the Gram type in bacteria whether bacteria were Gram-positive or negative. Gram difference in bacteria was shown from the purple staining for Gram-positive and red staining for

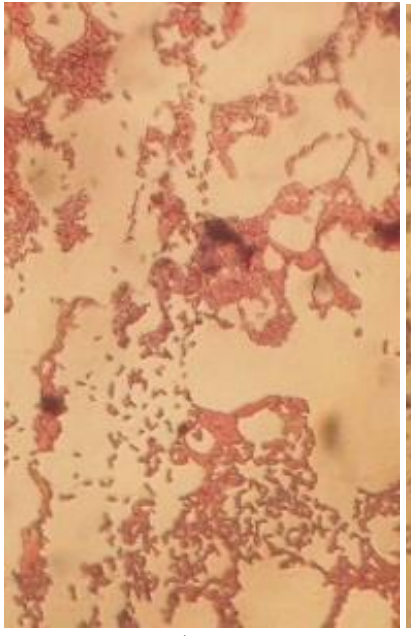

A

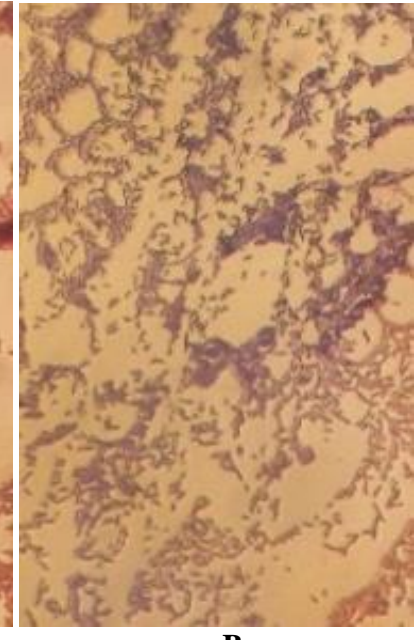

B
Figure 6. Gram staining; A.Gram negative mlp-1 isolate, B. Gram-positive mlp-2 isolate

Gram-negative. Beveridge (2001) and Wu and Yang (2020) stated that Gram staining was used to clarify whether Gram-positive and Gram-negative bacteria were. Gram staining is used for initial clarification in unknown isolates. Gram staining classifies bacteria based on cell-wall composition difference in bacteria, namely, peptidoglycans, lipopolysaccharides, and cell-wall thickness and thinness, which produces red color for Gram-negative bacteria and purple for Gram-positive bacteria.

Gram staining on the mlp-1 isolate produced red color, while the mlp-2 isolate produced purple color. This means that the mlp-1 isolate is Gram-negative bacteria and mlp-2 isolate is Gram-positive bacteria (Figure 6). Morphological cell observation indicates that the mlp- 1 and mlp- 2 isolates are rod-shaped bacteria with non-elevated circle-shaped colonies. In the mlp-2 isolate, the colony had radial line, while in the mlp-1 isolate, had no radial line (Figure 7). The results followed Krairitthichai and Thongwai (2005) who tested the morphological characteristics of bacterial colonies by observing shape, edge, elevation, radial line, color, motility, and Gram staining.

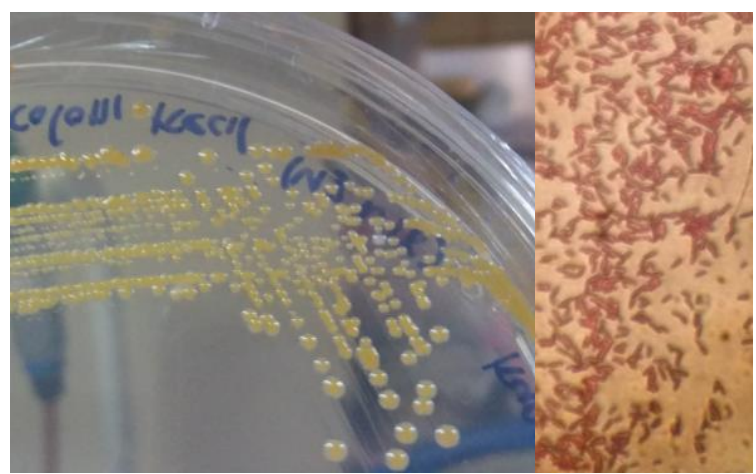

A

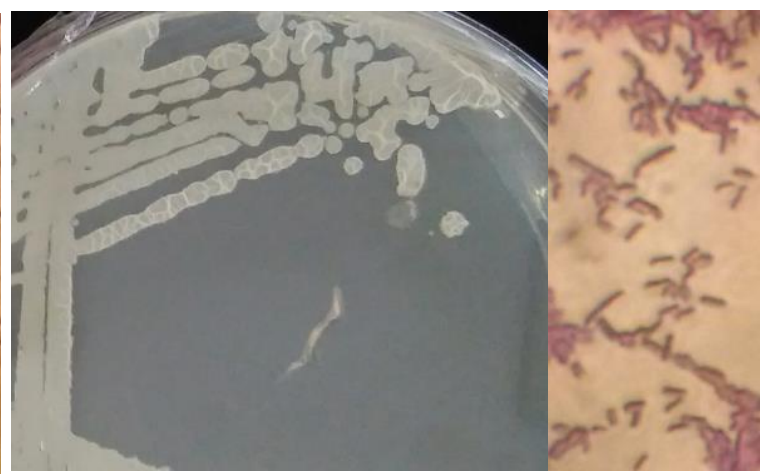

B

Figure 7. Morphological colony and rod shape cell; A. mlp-1 isolate, B. mlp-2 isolate 
The motility in both isolates on TSA media indicates that the mlp-1 and mlp-2 isolates are non-motile or negative motility as no bacteria spreading below the media in the form of root-like but the spreading occurred around the colony. This condition was similar to Cappuccino and Sherman (2017) who stated that the motility test was performed to identify the bacterial movement. Positive motility test was marked from bacteria spreading on stand agar media in the form of root-like, while negative motility was marked from bacterial spreading around the colony as former Ose needle puncture. Negative motility showed that bacteria had no flagella as movement tool.

\section{SrRNA molecular identification}

To support the bacterial identification from morphological and Gram staining observations, molecular identification was used based on the 16SrRNA encoding gene identification. Molecular identification is required as phenotypical identification does not provide sufficient information to differ interspecies and intraspecies strains. Moreover, phenotypical identification has low reproducibility due to bacterial characteristics that often change along with environmental changes (Duza and Mastan 2013).

RNA ribosomal encoding gene is conserved gene as the gene can be used as universal primers for Polymerase Chain Reaction (PCR) process which can be determined the nucleotide size through sequencing (Lau et al. 2002). The 16S rRNA region from the $\mathrm{A}$ and $\mathrm{B}$ isolates were amplified using the PCR technique based on (Lane et al. 1985), with 27F (5'-AGAGTTGATCCTGGCTCAG-3') and 1492R (5'-TACCTTGTTACGATT-3') primers. Frank et al. (2008) stated that the $27 \mathrm{~F}$ and $1492 \mathrm{R}$ primers were common primers used for $16 \mathrm{~S}$ rRNA bacterial genes with the amplicon of approximately 1465 base pairs.

Amplicon was obtained at 1500 base pairs from the electrophoresis result (Figure 8). After the amplicon was purified and sequenced, 1353 base pairs of amplicon were obtained from the mlp-1 isolate and 1431 base pairs from the mlp-2 B isolate The sequencing result based on the 16S rRNA encoding gene obtained from two isolates were used as molecular markers. The 16S rRNA encoding gene was characterized as ubiquitous with identical function in bacteria. The 16S rRNA gene has a region with conservative base sequence and variation base sequence. The ratio of conservative base sequence is useful to construct universal phylogenetic tree, while the variation base sequence is useful to track diversity and place strains in one species (Baker et al. 2003).

The rDNA sequence in the genetically correlated organism commonly has similarities, as each organism has certain kinship distance when being aligned. From the aligning result, determination based on the sequence that becomes the distinct characteristic of organism will be much easier (Lau et al. 2002).

The sequencing result was analyzed further through the online server in www.ncbi.nlm.nih.gov using the nucleotide Basic Local Alignment Search Tool (nucleotide BLAST) program. Donkor et al. (2014) stated that
BLASTn or nucleotide BLAST was used to identify sequences obtained based on the nucleotide database available in the GenBank. The 16S rRNA encoding gene sequence from various organisms that can or cannot be cultured have been formed in database. More than 4000 sequence databases of 16S rRNA were obtained from 1800 species (Botteger 1996).

By using BLAST program, the species name was obtained from the database which had similarities with the sequence entered. The BLAST result obtained from the $16 \mathrm{~S}$ rRNA sequence showed that the mlp-1 isolate had 98.43\% similarity to Chryseobacterium gleum.

The phylogenetic tree from the mlp-1 isolate showed the kinship and similarity relationship of $16 \mathrm{~S}$ rRNA to Chryseobacterium gleum, mainly Chryseobacterium gleum strain CIFRI-SRM4 and Chryseobacterium gleum isolate UM-AEU276 and showing difference from Lactobacillus plantarum as an outgroup (Figure 9).

Meanwhile, the mlp-2 isolate had $99.89 \%$ similarity to Bacillus velezensis. Based on the phylogenetic tree of the mlp-2 isolate, the mlp-2 isolate was in a similar branch to Bacillus velezensis strain FZB42 (Figure 10).

The phylogenetic tree showed that mlp-2 sequences had a close relationship with Bacillus velezensis, B. siamensis, B. amyloliquefaciens, B. Vallismortis, and B. subtilis showing difference from Lactobacillus plantarum and Pseudomonas flourescens as an outgroup. (Figure 10)

The identification results of $16 \mathrm{~S}$ rRNA showed different sequences between first and second sequences, which indicate that the mlp-1 and mlp- 2 isolates are different species. Based on Cai et al. (2003), the 16S rRNA can be used to determine taxonomy, phylogenics, and estimate the diversity distance among bacterial species.

The identification result of $16 \mathrm{~S}$ rRNA showed that the mlp-1 isolate was C. gleum from the Chryseobacterium genus as Gram-negative bacteria with aerobic, nonfermentative, yellow-pigmented colony, rod shape, and ubiquitous in nature. This genus inhabits soil environment (Weon et al. 2008; Shen et al. 2005), water environment (Kampfer et al. 2003), plants (Young et al. 2005; Venil et al. 2014; Jeong et al. 2017), and fish (Ilardi et al. 2019).

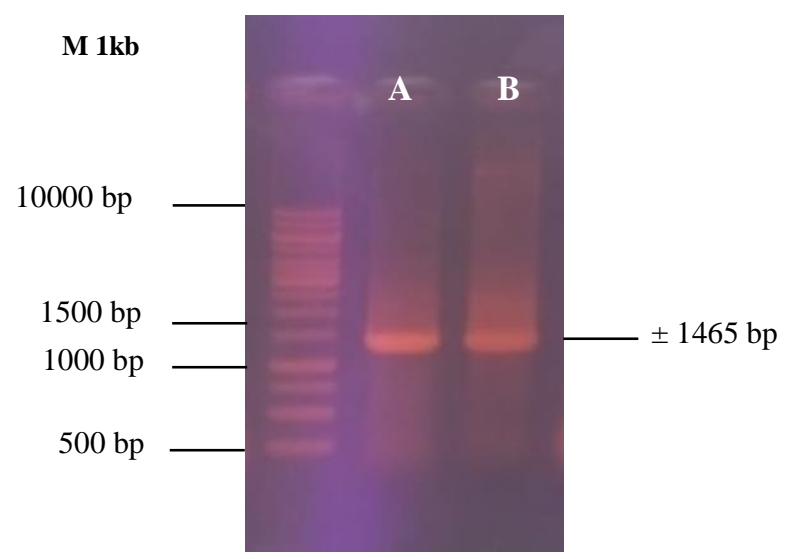

Figure 8. Electropherogram of $16 \mathrm{~S}$ rRNA amplicon: A. mlp-1 Isolate, B. mlp-2 Isolate 

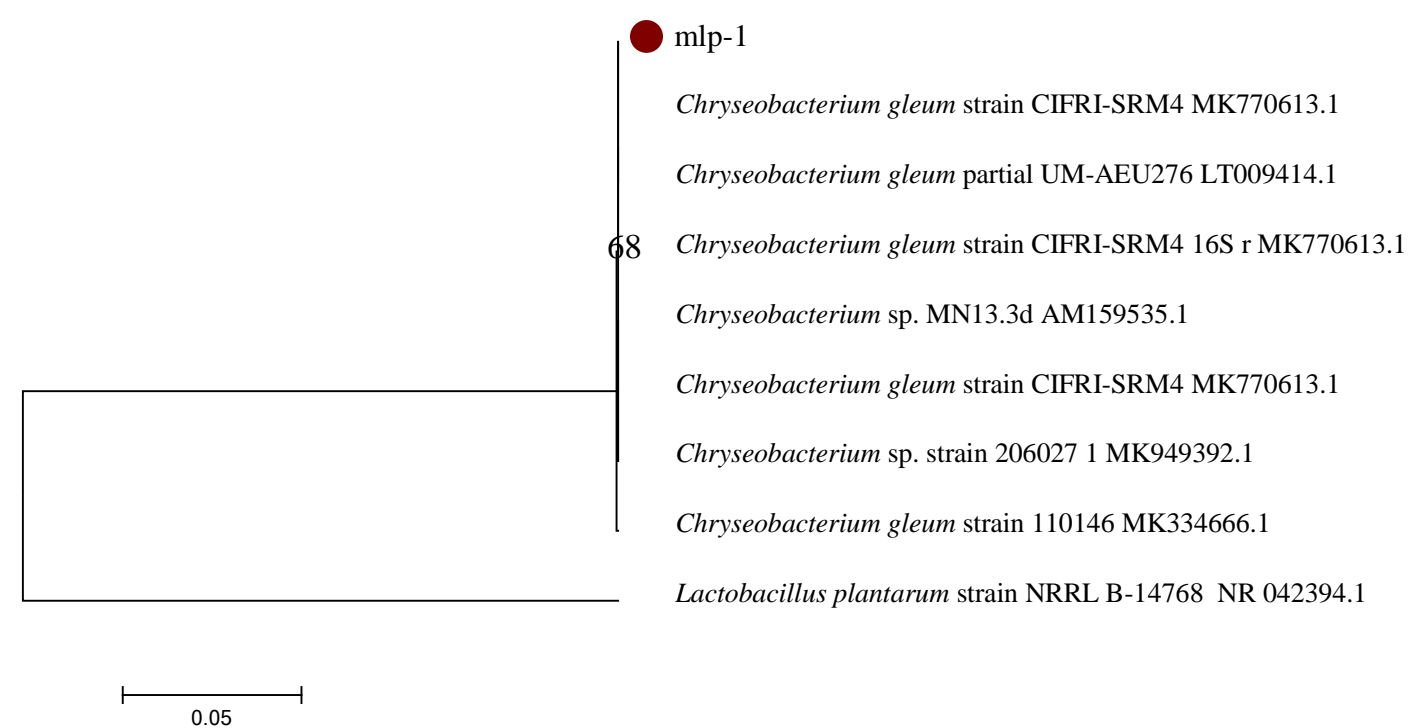

Figure 9. The mlp-1 isolate phylogenetic tree, using maximal likelihood method

Table 1. BLAST result of $16 \mathrm{SrRNA}$ sequence from the mlp-1 isolate

\begin{tabular}{|c|c|c|c|c|c|c|}
\hline Description & $\begin{array}{l}\text { Max } \\
\text { score }\end{array}$ & $\begin{array}{l}\text { Total } \\
\text { score }\end{array}$ & $\begin{array}{l}\text { Query } \\
\text { cover }\end{array}$ & $\begin{array}{l}\mathbf{E} \\
\text { value }\end{array}$ & Per. ident & Accession \\
\hline $\begin{array}{l}\text { Chryseobacterium gleum strain CIFRI-SRM4 16S } \\
\text { ribosomal RNA gene, partial sequence }\end{array}$ & 2246 & 2246 & $94 \%$ & 0.0 & $98.43 \%$ & MK 770613. 1 \\
\hline $\begin{array}{l}\text { Chryseobacterium gleum partial 16S rRNA gene, isolate } \\
\text { UM-AEU } 276\end{array}$ & 2246 & 2246 & $94 \%$ & 0.0 & $98.43 \%$ & LT 009414.1 \\
\hline $\begin{array}{l}\text { Chryseobacterium sp MN13.3d ribosomal RNA gene, } \\
\text { partial sequence }\end{array}$ & 2246 & 2246 & $94 \%$ & 0.0 & $98.43 \%$ & GQ916504.1 \\
\hline
\end{tabular}

Table 2. The BLAST result of 16SrRNA sequence from the mlp-2 isolate

\begin{tabular}{|c|c|c|c|c|c|c|}
\hline Description & $\begin{array}{l}\text { Max } \\
\text { score }\end{array}$ & $\begin{array}{l}\text { Total } \\
\text { score }\end{array}$ & $\begin{array}{l}\text { Query } \\
\text { cover }\end{array}$ & E value & Per. Ident & Accession \\
\hline $\begin{array}{l}\text { Bacillus velezensis strain FZB42 KX898131.1_16S } \\
\text { ribosomal RNA complete sequence }\end{array}$ & 1655 & 1655 & $100 \%$ & 0.0 & $99.89 \%$ & NR 075005_2 \\
\hline $\begin{array}{l}\text { Bacillus amyloliquefaciens strain KCTC } 1361316 \mathrm{~S} \\
\text { ribosomal RNA partial sequence }\end{array}$ & 1650 & 1650 & $100 \%$ & 0.0 & $99.76 \%$ & NR 117946_1 \\
\hline $\begin{array}{l}\text { Bacillus amyloliquefaciens strain VAL } 3 \\
\text { EU857428.1_16S ribosomal RNA partial sequence }\end{array}$ & 1650 & 1650 & $100 \%$ & 0.0 & $99.76 \%$ & NR 116240_1 \\
\hline
\end{tabular}

The Chryseobacterium species is rarely associated with humans as hosts, except the two closed species of Chryseobacterium, namely, C. gleum and C. indologenes (Lim et al. 2020). C. gleum is mainly associated with urinary bladder and pneumoniae (Tsouvalas et al. 2020). Based on this characteristic, the A isolate as Chryseobacterium gleum is not potential isolate for industrial application, therefore biochemical identification was not performed to confirm its identification.

Meanwhile, the Bacillus velezensis are rod-shaped Gram-positive bacteria with non-pathogenic Generally Recognized as Safe (GRAS) characteristics that are safe for various industrial sector applications, mainly in agroindustry and food industry, and health industry (Adeniji et al. 2019). Based on the application potential of
Bacillus velezensis in the industrial sector, identification was continued by using the biochemical test to identify the physiological and metabolism characteristics.

\section{Biochemical identification on the B isolate (Bacillus velezensis)}

The biochemical identification results on the Bacillus velezensis isolate can be shown below (Table 3).

The catalase test showed a positive result, which indicates that B.velezensis is aerobically marked from the existence of gas bubble in the culture after being dropped with $\mathrm{H}_{2} \mathrm{O}_{2} 3 \%$ solution. B.velezensis has catalase enzyme that can degrade toxic hydrogen peroxide into oxygen source. Botteger (1996) explained that organisms must rely on defense mechanisms to survive, which allow them to 
repair or avoid oxidative damage to hydrogen peroxide $\left(\mathrm{H}_{2} \mathrm{O}_{2}\right)$. Catalase neutralizes the damaging effects of hydrogen peroxide. During respiration, microorganisms, whether aerobes, facultative anaerobes, and microaerophiles, produce toxic $\mathrm{H}_{2} \mathrm{O}_{2}$ (Cappucino and Sherman 2005). Locke et al. (2013) stated that catalase is an enzyme that catalyzes the degradation of $\mathrm{H}_{2} \mathrm{O}_{2}$ to $\mathrm{H}_{2} \mathrm{O}$ and $\mathrm{O}_{2}$. Oxidase test showed a positive result observed from the blue color formation in the culture. Positive oxidase indicates that the B.velezensis produces oxidase enzyme. The oxidase enzyme plays a role in oxidase and electron reduction during the oxidative phosphorylation process (Cappuccino and Sherman 2005).

Indole production test showed negative results as no red layer or red ring on the media surface. B. velezensis did not produce tryptophanase enzymes, which could not hydrolyze tryptophan amino acid into indole or pyruvic acid. The red ring formation on surface medium occurred due to hydrolyzed indole as the indole in the medium was extracted to the Kovac's reagent layer by butanol acid component and formed p-dimethylaminobenzaldehyde complex (Cappuccino and Sherman 2005).

The sucrose, fructose, and glucose carbohydrate fermentation test showed positive results as the media turned yellow, but the bubble formation on the Durham tube was not followed. This condition indicates that carbohydrate fermentation of B.velezensis can alter carbohydrates to organic acids followed by gas formation. Hans (2020) stated that microorganisms could ferment carbohydrates to organic acids with gas formation. The acids formation comprised lactic acid, formic acid, acetic acid, butyric acid, butanol, and ethanol. Meanwhile, gas formation comprised carbon dioxide and hydrogen. Acid and gas formations produced a decrease in $\mathrm{pH}$, which altered media to yellow and bubble formation on the Durham tube.
Oxidative-fermentative test on B.velezensis produced media color changing from green to yellow on opened tube media, while color-changing was not found on closed tube media. This condition indicates that B.velezensis are oxidative bacteria. Tankeshwar (2016) stated that the oxidative-fermentative test (OF) developed by Hugh and Leifson in 1953 aimed to differentiate oxidative and fermentative bacteria. Oxidative bacteria produce acids from carbohydrate breakdown in aerobic conditions, while fermentative bacteria produce acids from carbohydrate breakdown in aerobic or anaerobic conditions.

The urease result was negative, based on the yellow color media. B. velezensis did not produce urease enzyme which showed no ammonia formation. However, positive reaction was shown by the media color changing to pink. This changing occurred due to the urease enzyme broke the carbon and nitrogen bonds to form ammonia. Ammonia in the media increases the $\mathrm{pH}$ to base, turning phenol red color indicator to pink (Cappuccino and Sherman 2005).

Table 3. Biochemical test results of B.velezensis isolate

\begin{tabular}{lc}
\hline \multicolumn{1}{c}{ Test } & Result \\
\hline Catalase & + \\
Oxidase & + \\
Indole production & - \\
Sucrose fermentation & + \\
Fructose fermentation & + \\
Glucose fermentation & + \\
Oksidative fermentative & Oxidative reaction \\
Urease & - \\
Citrate & - \\
Voges-Proskauer & + \\
Methyl red & + \\
H 2 production & - \\
Starch hydrolysis & + \\
Nitrate reduction & + \\
\hline
\end{tabular}

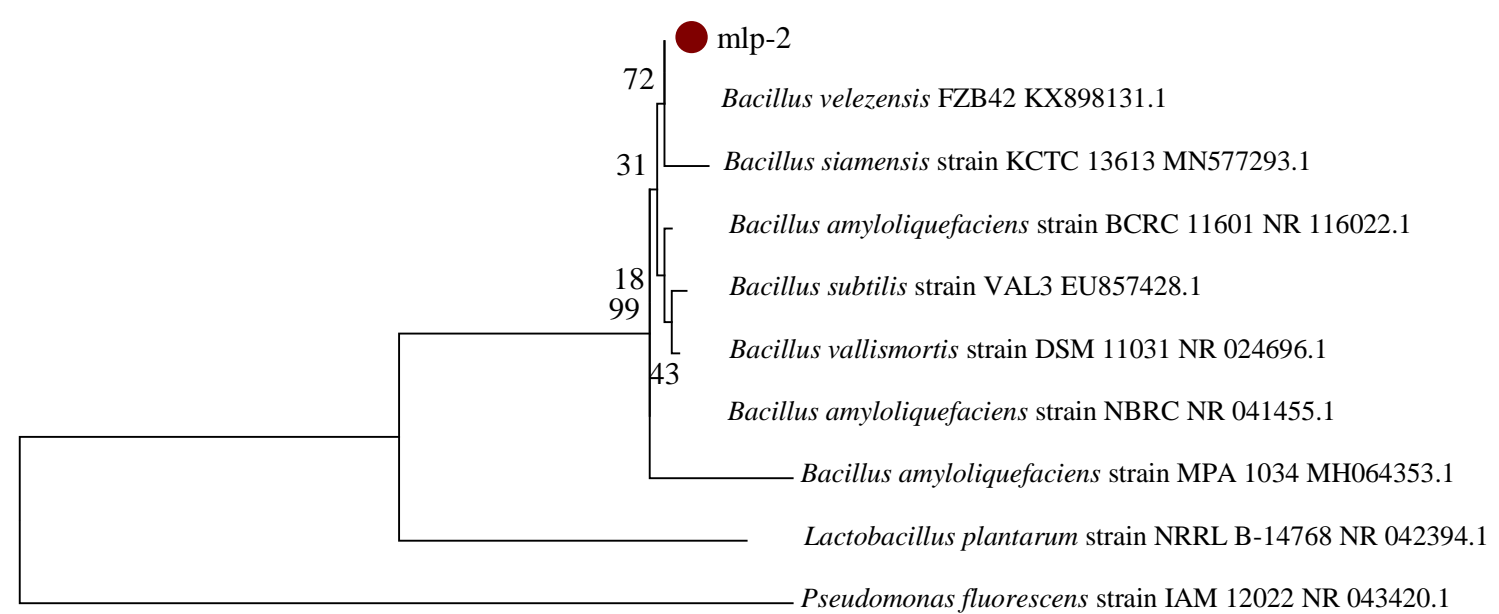

Figure 10. Phylogenetic tree of the mlp-2 isolate using maximal likelihood method 
Citrate test showed negative results as no color changing in the media. This means that B.velezensis are not included in Enterobacteriaceae family as not producing citric permease enzyme. Citrate test was used to differ bacteria from Enterobacteriaceae family based on the citrate usage as carbon source. Bacteria that grow on the media produce citric permease enzyme that turns citrate to pyruvic acid, as pyruvic acid is included in Krebs cycle for energy production (Aryal 2019). Voges Proskauer test showed positive results marked from the formation of red color, which indicates that B.velezensis can oxidize glucose to acids perfectly. Red color in methyl red test showed a positive result, as B.velezensis produced high acid concentration which could turn the media color. Therefore, Voges-Proskauer and Methyl Red tests are often performed together to evaluate organism capability in glucose oxidation by producing acids (Sunatmo 2007).

The pink color in the media on the $\mathrm{H}_{2} \mathrm{~S}$ production test showed a negative result, indicating that $B$. velezensis does not have the desulfurase enzyme to break down the amino acid cysteine into $\mathrm{H}_{2} \mathrm{~S}$. Cysteine is an amino acid that contains sulfur as under aerobic and anaerobic conditions, breaking down cysteine will produce different products. In aerobic conditions, the breakdown of cysteine will produce $\mathrm{H}_{2} \mathrm{~S}$, ammonia, acetic acid, and formic acid, while in aerobic conditions only produce $\mathrm{H}_{2} \mathrm{~S}$ (Bal et al. 2009). The starch hydrolysis test produced a clear zone on the media, which indicates that B.velezensis has amylase enzyme to break down complex carbohydrates into simple sugars. The starch hydrolysis test is one of the tests to identify bacteria biochemically, as bacteria with the amylase enzyme will break down starch into disaccharides and monosaccharides, therefore the agar media will produce a clear zone around the colony. Bacillus genera are known as one of the amylase-producing bacteria (Sigmon 2008).

The nitrate reduction test showed pink color on the media, which indicates that B.velezensis has nitrate reductase enzyme to reduce nitrate to nitrite. Bal et al. (2009) stated that positive nitrate reduction in reducing nitrate to nitrite is indicated from the formation of red color. Based on the biochemical test parameters obtained after being matched with the Cowan and Steel (1961), the isolates from oil palm processing waste are rod-shaped bacteria from Bacillus genus. These results have been supported by the molecular identification of 16SrRNA which showed that the isolate B had similarities with Bacillus velezensis.

Popoola et al. (2017) stated that there were five genera and seven species obtained from the screening result of oil processing company and its waste. The Bacillus, Pseudomonas, Flavobacterium and Alcaligenes genera were obtained with the specific species of Bacillus subtilis, Bacillus licheniformis, Pseudomonas cepacia, Pseudomonas fluorescens, Flavobacterium sp, Alcaligenes sp., and Candida parapsilosis. The screening result showed a lipolytic activity from the bacteria based on the clear zone formation on the media containing lipids or oil with high potential development in various industries.

\section{Bacillus velezensis inhibitory test}

The B. velezensis antagonistic test was performed to confirm the identification of the secondary metabolites produced, including antimicrobial compounds. The Bacillus genus is reported to produce more than 45 antimicrobial compounds used for clinical use, food preservatives, biocontrol or plant biopesticides (Baruzzi et al. 2011). Some of the distinct features of B. velezensis compared to Bacillus in one group based on ANI (Average Nucleotide Identity), namely, $B$. siamensis and $B$. amyloliquefaciens, $B$. velezensis synthesize more antimicrobial compounds than the two species in the same group (Chun et al. 2019).

Bacillus velezensis are known to have inhibitory capability with Gram-negative bacteria and other bacteria from Bacillus genus. Inhibition test was performed on bacterial isolates of $C$. gleum, B. halodurans $C M 1, B$. megaterium, B. stearothermophilus, B. subtilis DB104, B. lichenifromis F11.3, Lactobacillus lactis, and E. coli DH5 $\alpha$. The test results on C. gleum, B. halodurans CM1, B. megaterium, B. licheniformis $F 11.3$ showed the inhibitory activity of $B$. velezensis with the greatest inhibitory activity was against $B$. halodurans $C M 1$, indicated from a clear zone with more than $4 \mathrm{~mm}$ diameter (Figure 11). Whereas for B. stearothermophilus, B. subtilis DB104, Lactobacillus lactis, and $E$. coli DH5 $\alpha$ showed no inhibitory activity, as no clear zone formation around the B. velezensis colony (Figure 11).

The inhibition test or antagonist test in B. velezensis against several isolates produced an inhibition zone (Figure 11 ) and did not produce an inhibition zone (Figure 12). $B$. velezensis have been widely used as pathogen control agent in plants, because Bacillus velezensis produces various antimicrobial compounds, including surfactin, iturin, basilicin, fengicin, macrolactin, bacillia, difficidin, plantazolysin, amylocyclicin, basilabactin, mersacidin, ericin (Chen 2017).

\section{Discussions}

The identification results of lipase-producing bacteria from screening and isolation of oil palm processing sewage sludge in Malimping-Banten found two isolates with lipolytic activity. Qualitative test on TBA media resulted in a clear zone around the colony. The molecular identification result using 16SrRNA showed that the isolates were $C$. gleum and $B$. velezensis. The Chryseobacterium genus members are Gram-negative, aerobic, non-fermentative, yellow-pigmented rod-shaped bacteria and ubiquitous in nature. This genus inhabits soil environment (Weon et al. 2008; Shen et al. 2005), aquatic environment (Kampfer et al. 2003), plants (Young et al. 2005; Venil et al. 2014; Jeong et al. 2017), and fish (Ilardi et al. 2019). 


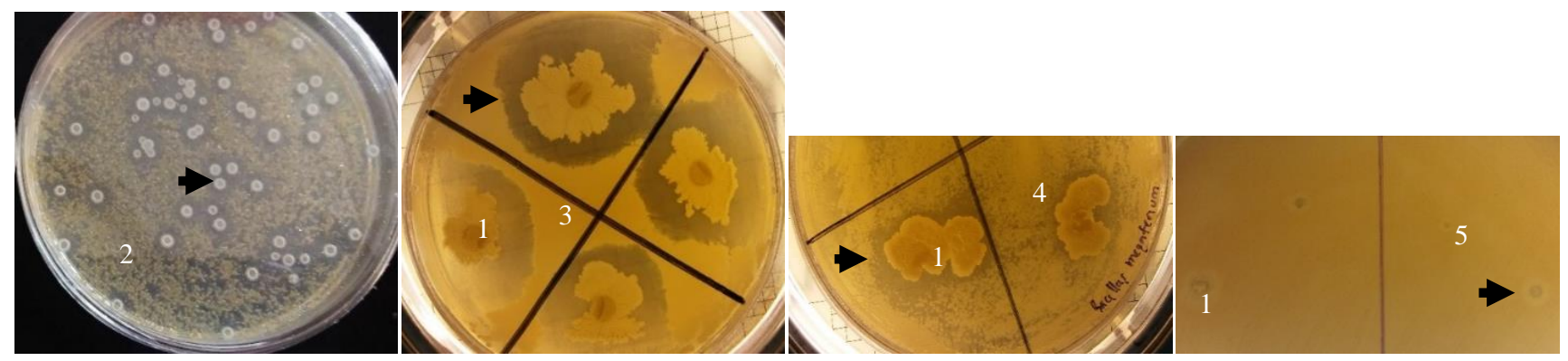

Figure 11. Bacillus velezensis inhibitory test; 1.B. velezensis, 2. C. gleum, 3. B. halodurans CM1, 4. B. megaterium, 5. B. licheniformis F11.3, Arrow: inhibitory zone

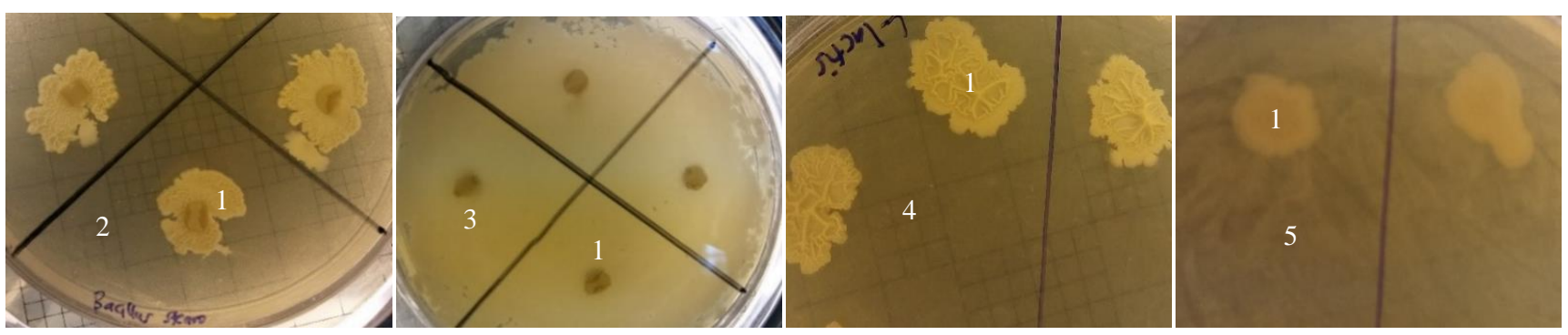

Figure 12. B. velezensis inhibitory test: 1. B. velezensis, 2. B. stearothermophilus, 3. B. subtilis DB104, 4. Lactobacillus lactis, 5. E. coli $\mathrm{DH} 5 \alpha$

Chryseobacterium species are rarely associated with humans as hosts, except for two adjacent Chryseobacterium species, namely, C. gleum and $C$. indologenes (Lim et al. 2020). Specifically, C. gleum association causes urinary tract infections and pneumonia (Tsouvalas et al. 2020).

Bacillus velezensis is a member of the Bacillus subtilis group complex. The grouping is based on the kinship relationship among species whose members are $B$. amyliliquefaciens, B. methylotrophicus, B. siamensis, $B$. subtilis, B. tequilensis, B. vallismortis, B. atrophaeus, B. mojavensis, and $B$. licheniformis. The Bacillus group complex and Bacillus species are known to be safe for feed and food product applications, and enzyme industry and biochemical product applications (Harwood et al. 2018). The Bacillus group complex and Bacillus species are safety guaranteed (Qualified Presumption of Safety /QPS) approved by the European Food Safety Authority (EFSA) (Fan et al. 2017).

In addition, Bacillus group complex or Bacillus species are commonly known to be safe (GRAS) stated by the USDA (US Food and Drug Administration) (Sewalt et al. 2016). Furthermore, several species from B. subtilis group complex produce secondary metabolites with antimicrobial activity, namely, polyketides, lipopeptides, siderophores, bacteriocins, bacteriocin-like inhibitory substances (BLIS), and non-ribosomally synthesized peptides (Harwood et al. 2018). Based on the B.velezensis inhibition test against $C$. gleum, B. halodurans CM1, B. megaterium, B. licheniformis F11.3, B.velezensis showed antimicrobial activity, indicated from the inhibition zone formation.
Among several complexes of the B. subtilis group, B.velezensis produces more antimicrobial compounds with greater inhibitory level than Bacillus species in one complex group. The results of biochemical identification indicates that the isolates are from Bacillus, and confirmed by molecular identification from isolation and screening tests that the isolate was B.velezensis.

In conclusion, identification of potential lipaseproducing bacterial isolates isolated from palm oil sewage sludge processing waste in Malimping Banten was Bacillus velezensis. Morphological and biochemical identification showed that the isolate was bacterial and belonging to the genus Bacillus, strengthened by molecular identification using 16SrRNA determined that the isolated bacterial isolate had a similarity of $99.89 \%$ with Bacillus velezensis strain FZB42.

\section{ACKNOWLEDGEMENTS}

Authors would like to thank BPPT for funding this project through DIPA BPPT 2018/2019, of the Indonesian Ministry of Research, Technology, and Higher Education for SDM Iptek Kemenristekdikti scholarship and laboratory of Agrotechnology and Biomedical Development for providing facilities to perform this project.

\section{REFERENCES}

Adeniji AA, Loots DT, Olubukola OB. 2019. Bacillus velezensis: phylogeny, useful applications, and avenues for exploitation. Appl Microbiol Biotech 1-13. DOI: 10.1007/s00253-019-09710-5 
Aryal S. 2019. Simmons Citrate Agar-Composition, Principle, Uses, Preparation and Result Interpretation. Microbiology for Beginners. New Delhi Press, New Delhi.

Bailey WR, Scott EG. 1974. Diagnostic microbiology, 4th ed. Mosby, St. Louis, MO.

Botteger EC. 1996. Approaches for identification of microorganisms. Despite longer experience with fatty acid profiles, DNA-based analysis offers several advantages. ASM News 62: 247-250.

Baker GC, Smith JJ, Cowan DA. 2003. Review and re-analysis of domain-specific $16 \mathrm{~S}$ primers. J Microbiol Methods 55: 541-555. DOI 0.1016/j.mimet.2003.08.009

Bal S, Mishra RR, Rath B, Sahu HK, Thatoi HN. 2009. Characterization and extracellular enzyme activity of predominant marine Bacillus spp. isolated from seawater of Orissa Coast, India. Malays J Microbiol 5 (2): 87-93. DOI: $10.21161 / \mathrm{mjm} .15108$

Beveridge T. 2001. Use of the Gram stain in microbiology. Biotech Histochem 76 (3): 111-118. DOI: 10.1080/bih.76.3.111.118

Baruzzi F, Quintieri.M, Morea M, Caputo L. 2011. Antimicrobial compounds produced by Bacillus spp. and applications in food. Sci Against Microb Pathogens 2 (1): 1102-1111.

Cowan ST, Steel KJ. 1961. Diagnostic tables for the common medica bacteria. J Hyg 59 (03): 357-373. DOI: 10.1017/S0022172400039024

Cai H, Archambault M, Prescott JF. 2003. 16S Ribosomal RNA sequencebased identification of veterinary clinical bacteria. J Vet Diagn Invest 15: 465-469. DOI: 10.1177/104063870301500511

Cappuccino JC, Sherman N. 2005. Microbiology: a laboratory manual.

Cappuccino JG, Sherman N. 2017. Microbiology: A Laboratory Manual The Benjamin Cumm, New York

Chen L. 2017. Complete genome sequence of Bacillus velezensis LM2303, a biocontrol strain isolated from the dung of wild yak inhabited Qinghai-Tibet plateau. J Biotechnol 251: 124-127. DOI: 10.1016/j.jbiotec.2017.04.034

Chun Byung H, Kyung Hyun K,Sang Eun,Che Ok J. 2019. Genomic and metabolic features of the Bacillus amyloliquefaciens group- $B$ amyloliquefaciens, $B$. velezensis, and B. siamensis- revealed by pangenome analysis. Food Microbiol 77: 146-157. DOI 10.1016/j.fm.2018.09.001

Derawi D, Abdullah BM, Zaman Huri H, Yusop RM, Salimon J, Hairunisa N, Salih N. 2014. Palm olein as renewable raw materials for industrial and pharmaceutical products applications: Chemical characterization and physicochemical properties studies. Adv Mat Sci Eng 2014. DOI: 10.1155/2014/134063

Duza MB, Mastan SA. 2013. Isolation, characterization and screening of enzyme-producing bacteria from different soil samples. Int J Pharm Bio Sci 4 (2): 813-824.

Donkor ES, Dayle NTKD, Adiku TP. 2014. Bioinformatics with basic local alignment search tool (BLAST) and fas alignment (FASTA). J Bioinfirm Seq Anal 6 (1): 1-6. DOI: 10.5897/IJBC2013.0086

Ed-Har AA, Rahayu W, Gunawan D. 2017. Isolasi dan identifikas mikroba tanah pendegradasi selulosa dan pektin dari rhizosfer Aquilaria malaccensis. Buletin Tanah Lahan 1 (1): 58-64. [Indonesian]

Frank JA, Reich CI, Sharma S, Weisbaum JS, Wilson BA, Olsen GJ. Critical evaluation of two primers commonly used for amplification of 16s rRNA genes. J Appl Environ Microbiol 74 (8): 2461-2470. DOI: 10.1128/AEM.02272-07

Fan B, Blom J, Klenk HP, Borriss R. 2017. Bacillus amyloliquefaciens, Bacillus velezensis, and Bacillus siamensis form an operational group $B$. amyloliquefaciens within the B. subtilis species complex. Front Microbiol 8: ID 22. DOI: 10.3389/fmicb.2017.00022

Glogauer A, Viviane P, Martini, Helisson F, Gustavo H, Couto, Marcelo MS, Rose AM, David AM, Emanuel MD, Fabio OP, Nadia K. 2011 Identification and characterization of a new true lipase isolated through metagenomic approach. Microb Cell Fact 10 (54): 1-15. DOI $10.1186 / 1475-2859-10-54$

Gurung N, Ray S, Bose S, Rai V. 2013. A broader view: Microbia enzymes and their relevance in industries, medicine and beyond. Biomed Res Int 2013. DOI: 10.1155/2013/32912

Geneaid. 2017. Geneaid instruction manual. Geneaid Biotech Ltd.

Haba E, Bresco O, Ferrer C, Marqués A, Busquets M, Manresa A. 2000. Isolation of lipase-secreting bacteria by deploying used frying oil as selective substrate. Enzyme Microb Technol 26: 40-44. DOI: 10.1016/S0141-0229(99)00125-8

Hasan F, Shah AA, Hameed A. 2006. Industrial applications of microbial lipase. Enzyme Microb Technol 39: 235-251. DOI 10.1016/j.enzmictec.2005.10.016
Harwood C R, Mouillon JM, Pohl S, Arnau J. 2018. Secondary metabolite production and the safety of industrially important members of the Bacillus subtilis group. FEMS Microbiol Rev 42 (6): 721-738. DOI: 10.1093/femsre/fuy028

Hans R. 2020. Carbohydrate (glucose) Fermentation Test: Uses, Principle, Procedure and Results. Laboratoryinsider.com

Ilardi P, Fernández J, Avendaño-Herrera R. 2009. Chryseobacterium piscicola sp. nov., isolated from diseased salmonid fish. Int Syst Evol Microbiol 59 (12): 3001-3005. DOI: 10.1099/ijs.0.007021-0

Jaeger KE, Eggert T. 2002. Lipase for biotechnology. Curr Opin Biotechnol 13 (4): 390-397. DOI: 10.1016/S0958-1669(02)00341-5

Jeong JJ, Lee DW, Park B, Sang MK, Choi IG, Kim KD. 2017. Chryseobacterium cucumeris sp. nov., an endophyte isolated from cucumber (Cucumis sativus L.) root, and emended description of Chryseobacterium arthrosphaerae. Int J Syst Evol Microbiol 67 (3): 610-616. DOI: 10.1099/ijsem.0.001670

Kämpfer P, Dreyer U, Neef A, Dott W, Busse HJ. 2003. Chryseobacterium defluvii sp. nov., isolated from wastewater. Int J Syst Evol Microbiol 53 (1): 93-97. DOI: 10.1099/ijs.0.02073-0

Krairitthichai S, Thongwai N. 2005. Isolation and screening for cellulaseproducing bacteria. The 34th Congress On Science And Technology Of Thailand. Bangkok, Thailand, oct $31^{\text {st }}$-nov $2^{\text {nd }} 2005$.

Lane DJ, Pace B, Olsen GJ, Stahlt DA, Sogint M, Pace NR. 1985. Rapid determination of $16 \mathrm{~S}$ ribosomal RNA sequences for phylogenetic analyses. Proc Natl Acad Sci 82: 6955-6959. DOI: 10.1073/pnas.82.20.6955

Lau SKP, Woo PCY, Teng JLL, Leung KW, Yuen KY. 2002. Identification by 16s ribosomal RNA gene sequencing of Arcobacter butzleri bacteraemia in a patient with acute gangrenous appendicitis. Mol Pathol 55 (3): 182-185. DOI: 10.1136/mp.55.3.182

Lee LP, Karbul HM, Citartan M, Gopinath SC, Lakshmipriya T, Tang TH. 2015. Lipase-secreting Bacillus species in an oil-contaminated habitat: promising strains to alleviate oil pollution. Biomed Res Int. DOI: $10.1155 / 2015 / 820575$

Lee P, Hudzaifah MK, Marimuthu C, Subash CB, Gopinat, Thanavel, Lakshmipriya, Thean HT. 2015. Lipase-secreting Bacillus species in an oil-contaminated habitat: promising strains to alleviate oil pollution. Biomed Res Int 1-9. DOI: 10.1155/2015/820575

Lim WG, Tommy T, Jactty C. 2020. Chryseobacterium indologenes and Chryseobacterium gleum interact and multiply intracellularly in Acanthamoeba castellanii. Exp Parasitol 211: 107862. DOI: 10.1016/j.exppara.2020.107862

Li H, Li L, Chi Y, Tian Q, Zhou T, Han C, Zhou Y. 2020. Development of a standardized Gram stain procedure for bacteria and inflammatory cells using an automated staining instrument. Microbiol Open 9 (9): 1-10. DOI: $10.1002 / \mathrm{mbo} 3.1099$

Li S, Yang X, Yang S, Zhu M, Wang X. 2012. Technology prospecting on enzymes: application, marketing and engineering. Comp Struct Biotechnol J 2: 225-230. DOI: 10.5936/csbj.201209017

Locke TS, Keat A, Walker, Mackinnon R. 2013. Microbiology and Infectius Diseases on The Move. Diterjemahkan oleh Akbarini, R. PT. Indeks. Jakarta. DOI: 10.1201/b13514 [Indonesian]

MacWilliam MP, Min KL. 2006. Luria Broth (LB) and Luria Agar (LA) Media and their uses protocol. ASM 1-10.

Madigan MT, Martinko J.M, Dunlap PV, Clark DP. 2009. Brock Biology of Microorganisms. $12^{\text {th }}$ edition. Pearson Benjamin Cummings Inc, USA.

Ma Q, Sun X, Gong S, Zhang J. 2010. Screening and identification of a highly lipolytic bacterial strain from barbecue sites in Hainan and characterization of its lipase. Ann Microbiol 60: 429-437. DOI: 10.1007/s13213-010-0060-1

Patel M, Mistry J, Desai S, Patel S, Desai S. 2016. Isolation and characterization of lipase-producing bacteria from vegetable oil spillage site. Int J Curr Microbiol Appl Sci 5 (8): 214-232. DOI: 10.20546/ijcmas.2016.508.023

Popoola BM, Onilude A A. 2017. Microorganisms associated with vegetable oil-polluted soil. Adv Microbiol 7: 377-386. DOI: 10.4236/aim.2017.75031

Palafox JC, Chavira BER, Bacac NR, Papayanopuolosd IM, Guadalupe V, Moorillon N. 2018. Improved method for qualitative screening of lipolytic bacterial strains. Elsevier 5: 68-74. DOI: 10.1016/j.mex.2018.01.004

Shen FT, Kämpfer P, Young CC, Lai WA, Arun A. 2005. Chryseobacterium taichungense sp. nov., isolated from contaminated soil. Int J Syst Evol Microbiol 55 (3): 1301-1304. DOI: 10.1099/ijs.0.63514-0 
Sunatmo TI. 2007. Eksperimen Mikrobiologi dalam Laboratorium. Ardy Agency, Jakarta. [Indonesian]

Sigmon Janie. 2008. The starch hydrolysis test. American society for microbiology, Washington, DC.

Sewalt V, Shanahan D, Gregg L, Marta JL, Carrillo R. 2016. The Generally Recognized as Safe (GRAS) process for industrial microbial enzymes. Ind Biotechnol 12 (5): 292-305. DOI: 10.1089/ind.2016.0011

Tankeshwar A. 2016. Bacteriology, culture media used in microbiology laboratory diagnosis of bacterial diseases. Microbiology 4: 31-35.

Tsouvalas CP, Mousa G, Lee AH, Philip JA, Levine D. 2020 Chryseobacterium gleum isolation from respiratory culture following community-acquired pneumonia. Am J Case Rep 21: e921172-1. DOI: 10.12659/AJCR.921172.

Verma N, Thakur S, Bhatt AK. 2012. Microbial lipases: Industrial application and properties (review). Int Res J Biological Sci 1 (8): 8892.
Venil CK, Nordin N, Zakaria ZA, Ahmad WA. 2014. Chryseobacterium artocarpi sp. nov., isolated from the rhizosphere soil of Artocarpus integer. Int J Syst Evol Microbiol 64 (9): 3153-3159. DOI: 10.1099/ijs.0.063594-0

Weon HY, Kim BY, Yoo SH, Kwon SW, Stackebrandt E, Go SJ. 2008. Chryseobacterium solisp.nov and Chryseobacterium jejuensesp.nov., isolated from soil samples from Jeju, Korea. Int $\mathbf{J}$ Syst Evol Microbiol 58 (2): 470-473. DOI: 10.1099/ijs.0.65304-0

Wu KY, Yang TX. 2020. A novel improved gram staining method based on the capillary. Pol J Microbiol 69 (4): 503-508. DOI: 10.33073/pjm-2020-043

Young CC, Kämpfer P, Shen FT, Lai WA, Arun A. 2005. Chryseobacterium formosense sp. nov., isolated from the rhizosphere of Lactuca sativa L. (garden lettuce). Int J Syst Evol Microbiol 55 (1): 423-426. DOI: 10.1099/ijs.0.63331-0 